\title{
The Efficiency of Applying the Internal Control Components Based on COSO Framework to Transparently Carry out Tasks and Services, Ensure Integrity and Enhance Quality and Efficiency: Case Study - The Greater Amman Municipality
}

\author{
Ola Muhammad Khersiat ${ }^{1}$ \\ ${ }^{1}$ Department of Accounting, Faculty of Economics and Administration Sciences, Zarqa University, Jordan \\ Correspondence :Dr. Ola Mohammad Khersiat, Department of Accounting, Zarqa University, P. O. Box 132222, \\ Zarqa 13110, Jordan. Tel: 962-779-069-109. \\ Received: December 30, 2019 \\ Accepted: February 3, 2020 \\ Online Published: March 22, 2020 \\ doi:10.5430/ijfr.v11n2p371 \\ URL: https://doi.org/10.5430/ijfr.v11n2p371
}

\begin{abstract}
This study aimed to measure the efficiency of employing the internal control components based on COSO framework to transparently carry out tasks and services, ensure integrity and enhance quality and efficiency, so as to contribute to promoting the adoption of internal control components based on the COSO framework, applying them and analyzing their efficiency in performing tasks transparently, ensuring integrity and enhancing quality and efficiency, particularly with the Amman`s Municipality efforts to create a directorate that operates the internal control while ensuring the integrity of the proceedings, carrying out tasks and services transparently and boosting citizen's confidence in the Greater Amman Municipality resolutions. One of the main findings of the study would be in the fact that the independent study variables represented in the internal audit based on the COSO framework has a highly positive impact in performing tasks transparently to ensure integrity, boost quality and efficiency at the Greater Amman Municipality. Results show that the communications systems component was the most highly applicable, followed by the follow-up and control procedures and activities, whereas the control environment came third, followed by risks and response procedures identification and assessment, and finally came the appropriate follow-up component in the fifth place.
\end{abstract}

Keywords: internal control, COSO, monitoring, information and communication, control activities, risk assessment, control environment

\section{Introduction}

The concept of internal control has developed significantly, particularly with the advent of international companies, multinational corporations. Building a system of internal control is essential for any facility since it represents the internal controls consisting of the policies and procedures to achieve the Administration`s objectives in administering its business in an orderly and efficient way, as well as protecting its assets, preventing and detecting fraud and wrongdoings, achieving accuracy and completeness of documents and accounting records, and preparing financial statements characterized by their reliability and relevance to the timely decision-making process. Moreover, an efficient and reliable internal control system contributes to reducing the costs of external audit and protects the facility against risks encountered as well as reducing its exposure to such risks.

The Committee of Sponsoring Organizations COSO has identified the framework that underlines the internal control domain and through which the efficiency of the internal control system is assessed. The Administration sets up and monitors an effective internal control system through a periodic review aiming to develop and improve the framework governing work and performance.

In 2001, the International Organization of Supreme Audit Institutions (INTOSAI) resolved to update the internal control standards instructions of 1992 in the government sector, to observe all the modern challenges in the field of internal control and introduce the concept of the Committee of Sponsorship Organizations`report (COSO) that being an internal control report in the (INTOSAI) integrated framework document. The application of COSO aims at contributing to the general awareness of internal control and setting instructions to create an effective internal control 
system in the government sector since such will probably increase the probability of achieving the intended objectives. (INTOSAI-GOV-9100)

The internal control is considered an integral part of modern governance systems and an essential tool to detect and combat corruption. The Middle East countries economies have started reforms of the public administrations so as to enhance integrity and transparency, as well as detect and combat corruption to achieve good governance and restore the citizen`s confidence in government institutions. Reforms have centered on public administration and accountability, with a view to providing result-oriented balances and data. Such reforms were crowned with the development of an internal control system which focused on financial discipline as well as monitoring public spending.

In Jordan, internal control officials comply with the financial control regulations No. 3 of 2011 issued by the Ministry of Finance when carrying out their tasks. The legal provisions of the internal control and audit are standard and comply with the Institute of Internal Auditors instructions; nevertheless, comprehensive and prior audit proceedings of the internal control are undertaken, focusing on three separate actors: (http://www.oecd.org/gov/ethics/corruption-risks-internal-control-mena-AR.pdf)

1- Auditors assigned and participants in the implementation of the budget in ministries, departments and government bodies.

2- Ministry of Finance control inspectors at ministries, departments and government bodies.

3- The Court of Audit auditors carry out $25 \%$ of their work at ministries, departments and government bodies

Compared with most countries in the Middle East, Jordan has made significant progress in relation to the improvement of the overall accounting area. It is paving the way to adopt the international accounting standards for the public sector. It considers, in its budget, the performance to keep abreast of global trends in improving the efficiency of the Public Administration. As indicated in the annual control report of the EU Financial Management of November 2015, that Jordan adopts programs proved credible and relevant to improving public financial management. The report concluded that the country conforms to the eligibility criterion to the improvement of the public financial management to support the budget. The report pointed out that Jordan has made progress mainly in the process of preparing the overall budget, collecting tax arrears, offering the information system of the public financial administration to the extra balance entities, resolving governmental arrears and preparing compliance regulations.

The report also noted that:

- $\quad$ Setting more internal control units that work effectively.

- Progressing towards modernizing the internal control and the external auditing.

- Transferring cases to the Public Prosecutor by the Integrity and Anti-corruption Authority.

The 2011 Public Expenditure and Financial Accountability report reviewed the performance changes in the public financial management system since 2007. The report noted the progress made by Jordan in budget credibility and the containment of expenditure, and that the budget is prepared in a comprehensive and transparent way. It also pointed out to the negative impact of political factors on many of the indicators, and that the public expenditure assessment and the financial accountability in Jordan have been completed for the year 2016, though not made available in its final version to the public. Moreover, the six areas intended for improvement in 2011 were audit and external audit where public expenditure and financial accountability values have witnessed significant improvements through the Accounting Office in relation tothe external dimensions in contrast with the significant improvements on the internal audit. http://www.oecd.org/gov/ethics/corruption-risks-internal-control-mena-AR.pdf

\section{Literature Review}

Through a review of previous studies related to internal control based on the COSO framework, it is found that a range of these studies have focused on the efficiency of internal control systems in governmental units, most notably Bierstaker study (2004) which looked at the impact of internal control on the quality of the employees ' performance in some Swedish public sector institutions. One of its main results was the positive impact of internal control systems on the employees` performance quality in terms of performance speed and accuracy. There is also a relationship of personal and career variables of public sector employees between the internal control systems and performance(.Ghoneimat and Siam ,2010), (Mahmoud, Abdullah, 2017) conducted a research on the factors affecting the efficiency of the internal control system in public sector institutions in Jordan. The study concluded that employees at the internal control in Jordanian ministries are university degrees holders. This confirms the attention 
paid by the Jordanian government to internal control. The study also concluded the poor efficiency of these ministries` internal control employees, in addition to the lack of clear criteria to performance assessment and the poor internal control employees`experience. Moreover, it concluded that a poor administrative and legislative authority prevails while the executive authority dominates. (Mahmoud, Abdullah, 2017) clarified the impact of e-government on internal control, indicating the advantages and disadvantages of such application on internal control, while trying to set a proposal for the development of electronic internal control methods to meet the application of e-government.

Another group of studies focused on internal control in accordance with the COSO system components, the most prominent of these (Al-Qada, 2017), (Al Sawalaqa \& Qtish, 2012), (Angeline \& Teng, 2018), (Rubino \& Vitolla, 2014), (Silmi, et al, 2014), (Ayagre, et al., 2014) and (Joseph, et al, 2015). Al-Qada (2017) aimed to grasp the impact of internal control in accordance with the COSO committee's resolutions on the analysis of credit risk based on 5C"S methodology in the commercial banks of Jordan. The study found a statistically significant impact for internal control revealed in (control environment, control procedures, risk assessment, information system and reach, supervision and guidance) on credit risk analysis based on 5C"S methodology in the commercial banks of Jordan. (Al Sawalaqa \& Qtish, 2012) aimed to study the relationship between the three COSO components (risk assessment, control environment and control activities) and the efficiency of the audit program in Jordan. Results showed that risk assessment highly contributes to an effective audit program. They also indicate that Jordanian companies lack the necessary expertise to deal with current tools that assess internal control.

(Angeline \& Teng, 2018) aimed to visualize the ERM framework among small and mid-sized companies in Malaysia and analyze its impact on sales. Results showed that small and mid-sized companies focus heavily on control and risk, being classified as the highest components in the ERM framework in small and mid-sized companies in Malaysia. Other components such as information and communication, control activities, risk and control assessment and monitoring were shown to have impact on sales.

(Rubino \&Vitolla, 2014) explained the relationship between the COSO, COBIT framework by clarifying ways of reducing the problems associated with information and technology. Analysis results also indicated that when using the COBIT framework, effective controls that provide significant gains to information technology are adopted, and that there is a direct effect of information technology control objectives on weakness points. Selmi, et al., 2014 confirmed that, if industrial companies apply the COSO system elements, the internal control system will be improved dramatically, economization achieved and costs of production lowered. This will enhance the competitive position of companies. Moreover, industrial companies' commitment to the internal control environment improves the internal control system. Results also showed that complying with the risk assessment, internal control and the internal control main activities contained within the standard internal control framework would improve the internal control system at Jordanian industrial companies.

Other studies focused on internal control based on the COSO model in banks. Most notably, Ayagre, et al. (2014) and Joseph, et al (2015). Ayagre, et al. (2014) aimed to evaluate the efficiency of internal control systems as revealed in control environment and follow-up activities based on the COSO standards in the banks of Guinea. Results indicated the presence of robust control regulations for the sub-components of the control environment, as well as for the internal control systems follow-up element. Joseph, et al. (2015) grasped the impact of COSO components on the detection and prevention of fraud in the Department of Treasury at Kenyan banks. Results indicated that there is a positive relationship between internal control systems in Kenyan banks and fraud detection and prevention. The ranking of such components vary; control activities came first followed by control environment and last came information and communication system.

\section{Study Features}

This study was distinguished of the application of COSO components in the public sector so as to contribute to promoting the adoption of internal control components based on the COSO framework, applying and analyzing their efficiency in performing tasks transparently, and enhancing quality and efficiency in the Jordanian public sector, but previous studies examined internal control in the public sector without applying of COSO components, while other studies were focusing on internal control based on the COSO model in the private sector.

\section{Research Method}

Amman Municipality has paved a long way in restructuring its services sectors with the aim of modernizing its administrative body by strengthening the positive aspects and dealing with the negative ones. 
The municipality is seeking to develop an internal control and audit directorate that has the capacity to embrace the Municipality`s services and financial allocations, relying on outputs and recommendations by relevant experts. This development occurred in response to a number of requirements, including the Court of Audit, which emphasizes its role in subsequent audit and requires the establishment of a directorate that will work on internal control in a prior stage. (https://www.ammancity.gov.jo/ar/resource/snews.aspx?id=5097DD10-C5E3-430B-8F3E-4D1CBA6F0EFD)

\subsection{Hypothesis and Methodology}

\subsubsection{The Study Hypothesis}

This study is based on a major hypothesis and five sub-hypotheses:

$\mathrm{H}_{0 \text { : }}$ There is no statistical significance impact of the efficiency of employing the internal control components based on COSO framework to carry out tasks and services transparently, ensure integrity, boost efficiency and quality at the Greater Amman Municipality.

$\mathrm{H}_{01:}$ : There is no statistical significance impact of the efficiency of employing the control environment based on COSO framework to carry out tasks and services transparently, ensure integrity and boost efficiency and quality at the Greater Amman Municipality.

$\mathrm{H}_{02}$ : There is no statistical significance impact of the efficiency of employing risks assessment based on COSO framework to carry out tasks and services transparently, ensure integrity, boost efficiency and quality at the Greater Amman Municipality.

$\mathrm{H}_{03:}$ There is no statistical significance impact of the efficiency of employing control activities based on COSO framework to realize the tasks and services to ensure transparency boost integrity and quality at the Greater Amman Municipality.

$\mathrm{H}_{04}$ : There is no statistical significance impact of the efficiency of employing suitable communications systems based on COSO framework to carry out tasks and services transparently, ensure efficiency and boost integrity and quality at the Greater Amman Municipality.

$\mathrm{H}_{05}$ : There is no statistical significance impact of the efficiency of employing suitable follow-up activities based on COSO framework to carry out tasks and services transparently, ensure efficiency and boost integrity and quality at the Greater Amman Municipality.

The internal consistency range test of the questionnaire statements was used, by measuring Cronbach Alpha, since it depends on the consistency of the respondents` performance from a statement to another. It indicates the correlation among the questionnaire`s statements. Moreover, Cronbach Alpha assesses reliability. Table 1 showes that the value of reliability amounted to $80.5 \%$, indicating the possibility of the results reliability that may result from the questionnaire when applied, since the mentioned figures are greater than $60 \%$, that being the minimum acceptable range of Cronbach Alpha. In the light of the above, the researcher has ascertained the reliability and consistency of the study tool (questionnaire), thus ensuring the validity of the study and its reliability in results analysis as well as answering the study questions and hypotheses.

Table 1. Reliability statistics

\begin{tabular}{ll}
\hline Cronbach's Alpha & No. of items \\
\hline 0.805 & 87 \\
\hline
\end{tabular}

The study statements have been analyzed and discussed in the light of the study questions and hypotheses identified by the researcher through the use of all of the arithmetic means and standard deviations, and the importance of the statement to describe the study sample towards the questionnaire statements.

Is there an application of internal control components based on COSO framework to carry out tasks and services transparently, ensure integrity and boost quality and efficiency at Greater Amman Municipality?

To answer the study first question, the arithmetic means were calculated and compared to the testing criterion of (3) out of (5) degrees and the arithmetic means of the study sample individuals responses to all statements. This aims at identifying the degree of interest of the study sample individuals to each mentioned statement, as well as the dispersion of answers from their arithmetic means. The following is a detailed description of the study sample individual is responses regarding each component of the COSO internal control components: 
1- Is there application of the control environment based on COSO framework to carry out tasks and services transparently, ensure integrity and boost quality and efficiency at Greater Amman Municipality?

Table 2. Statement (control environment)

\section{statement (control environment)}

Provision of guidelines and regulations by Greater Amman Municipality to identify financial and administrative tasks and auditing to carry out tasks and services, ensure integrity and boost quality and efficiency.

Communication and interaction between the senior administration of the Greater Amman Municipality and the various departments to carry out tasks and services ensure integrity, boost quality and efficiency.

\begin{tabular}{llll}
\hline Recruitment policies & 2.1385 & 0.768 & 39 \\
\hline All statements & 4.1359 & 0.37 & \\
\hline
\end{tabular}

The results shown in Table 2 indicate an increase in the overall arithmetic mean of the control environment statements, reaching a standard deviation of (4.1359). Statement (37) stating that "Provision of guidelines and regulations by Greater Amman Municipality to identify financial and administrative tasks and auditing" ranked first as a priority and interest to the study sample individuals with an arithmetic mean of (4.8923) and standard deviation (089.) The statement stating that " there is communication and interaction between the senior administration at the Greater Amman Municipality and the various departments" ranked first as a top priority and main interest for the study sample individuals with an arithmetic mean of (4.8923) and standard deviation of (089.), whereas the statement stating " the existence of special policies regarding recruitment" ranked last with an arithmetic mean of (2.1385) and standard deviation of (0.768) as compared with the overall arithmetic mean and overall standard deviation of the year. These results indicate that the sample individuals have application of each statement of the control environment statements.

2- Is there application of the risk assessment based on COSO framework to carry out tasks and services transparently, ensure integrity and boost quality and efficiency at Greater Amman Municipality?

Table 3. Statement (risk assessment)

\begin{tabular}{|c|c|c|c|}
\hline statement (risk assessment) & $\begin{array}{l}\text { Arithmetic } \\
\text { mean }\end{array}$ & $\begin{array}{l}\text { Standard } \\
\text { deviation }\end{array}$ & Order \\
\hline $\begin{array}{l}\text { Adequate resources to achieve the goals to carry out tasks and services } \\
\text { ensure integrity and boost quality and efficiency. }\end{array}$ & 4.8154 & 0.39 & 1 \\
\hline $\begin{array}{l}\text { The main risks are specified for each major goal related to the } \\
\text { completion of tasks and services, ensuring integrity and enhancing the } \\
\text { quality and efficiency at administrative levels. }\end{array}$ & 2.9846 & 0.33 & 17 \\
\hline All statements & 4.0869 & 0.39 & \\
\hline
\end{tabular}

Results shown in Table 3 indicate an increase in the overall arithmetic mean of risk assessment statements reaching (4.0869) with a standard deviation(0.39).The arithmetic mean was found to be greater than the test standard and the level of assessment of the study sample individuals of all the sample statements was positive and high. The statement stating that "the presence of adequate resources needed to achieve goals" ranked first as a top priority and main interest for the study sample individuals with an arithmetic mean of (4.8154) and standard deviation of (0.39), whereas the statement" the main risks are specified for each key objective on administrative levels" ranked last with an arithmetic mean of (2.9846) and standard deviation of $(0.33)$ compared with the overall arithmetic average and overall standard deviation. These results indicate that the sample individuals have application of each statement of the risk assessment statements. 
Table 4. Statement (control activities)

\section{statement (control activities)}

Policies and procedures are set in a way that ensures abiding by the administrative directives regarding carrying out tasks and services, ensure integrity and boost quality and efficiency at Greater Amman Municipality.

\begin{tabular}{lll}
$\begin{array}{l}\text { Arithmetic } \\
\text { mean }\end{array}$ & $\begin{array}{l}\text { Standard } \\
\text { deviation }\end{array}$ & Order \\
\hline 4.8923 & 0.31 & 1 \\
& &
\end{tabular}

The actual performance of tasks and services was reviewed against planned performance, or compare units with other ones or the historical comparison to the Municipality over years.

$4.0923 \quad 0.29 \quad 6$

All statements
4.3641

0.39

Results shown in Table 4 indicate an increase in the overall arithmetic mean of control activities statements reaching (4.3641) with a standard deviation(0.39). The arithmetic mean was found to be greater than the test standard and the level of assessment of the study sample individuals of all the sample statements was positive and high. The statement stating that " policies and procedures are set in a way that complies with the administrative directives" ranked first in priority and a main interest for the study sample individuals with an arithmetic mean of (4.8923 and standard deviation of (0.31), whereas the statement stating that " The actual performance is reviewed against planned performance, or units are compared with other ones or the historical comparison to the Municipality performance over years" ranked last with an arithmetic mean of (4.0923) and standard deviation of (0.29) compared with the overall arithmetic mean and the overall standard deviation. Results show that the study sample individuals have application of each of the follow-up and control procedures and activities statements.

3- Is there application of the appropriate communication systems based on COSO framework to carry out tasks and services transparently, ensure integrity and boost quality and efficiency at Greater Amman Municipality?

Table 5. Statement (appropriate communication systems)

\begin{tabular}{|c|c|c|c|}
\hline statement (appropriate communication systems) & $\begin{array}{l}\text { Arithmetic } \\
\text { mean }\end{array}$ & $\begin{array}{l}\text { Standard } \\
\text { deviation }\end{array}$ & Order \\
\hline $\begin{array}{l}\text { Setting mechanisms to provide directors with the necessary information for } \\
\text { carrying out tasks and services, ensure integrity and enhance the quality } \\
\text { and efficiency of Greater Amman Municipality }\end{array}$ & 4.8308 & 0.38 & 1 \\
\hline $\begin{array}{l}\text { Strategic plans are set to develop information systems to carry out tasks and } \\
\text { services, ensure integrity and enhance the quality and efficiency of Greater } \\
\text { Amman Municipality }\end{array}$ & 4.1385 & 0.35 & 11 \\
\hline All statements & 4.4993 & 0.43 & \\
\hline
\end{tabular}

Results shown in Table 5 indicate an increase in the overall arithmetic mean of appropriate communication systems statements reaching (4.8308) with a standard deviation(0.38). The arithmetic mean was found to be greater than the test standard and the level of assessment of the study sample individuals of all the sample statements was positive and high. The statement stating that " Setting mechanisms to provide directors with the necessary information" ranked first in priority and a main interest for the study sample individuals with an arithmetic mean of (4.8308) and standard deviation of (0.38), whereas the statement stating that" Strategic plans are set to develop information systems" ranked last with an arithmetic mean of (4.1385) and standard deviation of (0.35) compared with the overall arithmetic mean and the overall standard deviation. Results show that the study sample individuals have application of each of the appropriate communication systems statements.

4- Is there application of the appropriate follow-up activities based on COSO framework to carry out tasks and services transparently, ensure integrity and boost quality and efficiency at Greater Amman Municipality? 
Table 6. Statement (appropriate follow-up activities)

\begin{tabular}{|c|c|c|c|}
\hline statement (appropriate follow-up activities) & $\begin{array}{l}\text { Arithmetic } \\
\text { mean }\end{array}$ & $\begin{array}{l}\text { Standard } \\
\text { deviation }\end{array}$ & Order \\
\hline $\begin{array}{l}\text { Regulations are designed to continuously monitor activities, tasks and } \\
\text { services, ensure integrity and enhance quality and efficiency }\end{array}$ & 4.8923 & 0.31 & 1 \\
\hline $\begin{array}{l}\text { Default is addressed and staff performance developed through performance } \\
\text { evaluation reports on their accomplishment of tasks and services. }\end{array}$ & 2.9077 & 0.42 & 14 \\
\hline All statements & 4.0648 & 0.40 & \\
\hline
\end{tabular}

Results shown in Table 6 indicate an increase in the overall arithmetic mean of appropriate follow-up activities statements reaching (4.0648) with a standard deviation(0.40). The arithmetic mean was found to be greater than the test criterion and the level of assessment of the study sample individuals of all the sample statements was positive and high. The statement stating that "Regulations are designed to continuously monitor activities" ranked first in priority and a main interest for the study sample individuals with an arithmetic mean of (4.8923) and standard deviation of (0.31), whereas the statement stating that " Default is addressed and staff performance developed through performance evaluation reports" ranked last with an arithmetic mean of (2.9077) and standard deviation of (0.42) compared with the overall arithmetic mean and the overall standard deviation. Results show that the study sample individuals have application of each of the appropriate follow-up activities statements.

After the researcher has presented the detailed description of the statements regarding the efficiency of the application of internal control components based on COSO framework to carry out tasks and services in a transparent way, ensure integrity and boost quality and efficiency at Greater Amman Municipality, he has tended to clarify in Table (7) the arithmetic means and standard deviations, and order the relative importance of the study sample individuals estimations on the range of the efficiency of the application of the internal control components based on the COSO framework to carry out tasks and services transparently, ensure integrity and boost quality and efficiency at the Greater Amman Municipality.

Table 7. COSO internal control framework

\begin{tabular}{llll}
\hline COSO Internal Control Framework & Arithmetic mean & Standard deviation & Order \\
\hline $\begin{array}{l}\text { Identification and assessment of risks and } \\
\text { response actions. }\end{array}$ & 4.0869 & 0.37 & 4 \\
\hline Communication systems. & 4.4993 & 0.43 & 1 \\
\hline Control activities and procedures. & 4.3641 & 0.39 & 2 \\
\hline Control environment. & 4.1359 & 0.37 & 3 \\
\hline Appropriate follow-up activities. & 4.0648 & 0.39 & 5 \\
\hline
\end{tabular}

Results outlined in Table 7 indicate that communication systems ranked first in priority for the study sample individuals at the Greater Amman Municipality with an arithmetic mean of (4.4993) and standard deviation of (0.43), whereas the control procedures and activities came second with an arithmetic mean of (4.3641) and standard deviation of (0.39), the control environment came third with an arithmetic mean of (4.1359) and a standard deviation of (0.37), while fourth came the risks assessment with an arithmetic mean of (4.0869) and standard deviation of (0.37), and fifth ranked the appropriate follow-up element as last in priority for the study sample individuals at the Greater Amman Municipality with an arithmetic mean of (4.0648) and a standard deviation of (0.39).

Results indicated that all the calculated arithmetic means of the previous components are larger than the test criterion amounted to (3) out of (5) degrees. These results suggest that the level of assessment of the study sample individuals at the Greater Amman Municipality for the extent of efficiency of the internal control components based on COSO framework to carry out tasks and services transparently, ensure integrity and boost quality and integrity was positive and that the degree of application of internal control components based on COSO framework to carry out tasks and services transparently, ensure integrity and boost quality and integrity was high from the point of view of the study sample individuals. 
$\mathrm{H}_{0}$ : There is no statistical significance impact of the efficiency of applying the internal control components based on COSO framework to carry out tasks and services, ensure integrity, boost efficiency and quality at the Greater Amman Municipality at the level of significance $(\alpha \leq . \mathbf{0 . 0 5})$

To test this hypothesis, the researcher used the one sample -test. Results described in (8) show the views of the study sample individuals concerning the efficiency of the application of the internal control components based on COSO framework to carry out tasks and services transparently, ensure integrity and boost quality and efficiency at Greater Amman Municipality.

Table 8. One sample T-test

\begin{tabular}{lllll}
\hline Statistical decision & Level of significance & T value & Standard deviation & Arithmetic mean \\
\hline Rejection of the (H0) & 0.000 & 11.173 & 0.40 & 4.23022 \\
\hline
\end{tabular}

The scheduled $\mathrm{T}$ value at the level of significance $(\boldsymbol{\alpha} \leq .0 .05)$ and degree (63) equals to 2.0, and in general, it is indicated that the arithmetic mean of all statements is 4.23022 and the calculated $\mathrm{T}$ value equals 11.173 , being greater than the $\mathrm{T}$ value that equals 2.00 , and a level of significance that equals $(0.000)$ which is less than $(\boldsymbol{\alpha} \leq .0 .05)$, so the null hypothesis $\left(\mathrm{H}_{0}\right)$ is rejected, and, stating that " there is statistically significant impact of the extent of efficiency of application of internal control components based on COSO framework to carry out tasks and services transparently, ensure integrity and boost quality and efficiency at Greater Amman Municipality at the level of significance ( $\alpha \leq .0 .05)$

$\mathrm{H}_{01}$ : There is no statistically significant impact for the extent of the efficiency of applying control environment based on COSO framework to carry out tasks and services transparently, ensure transparency and boost quality and integrity at Greater Amman Municipality at the level of significance $(\boldsymbol{\alpha} \leq .0 .05)$ To test this hypothesis, the researcher used the one sample T-test. Results as shown in (Table 9) indicate the views of the study sample individuals.

Table 9. One sample T-test

\begin{tabular}{|c|c|c|c|c|c|c|}
\hline & \multicolumn{6}{|c|}{ Test Value $=3$} \\
\hline & \multirow[b]{2}{*}{$\mathrm{T}$} & \multirow[b]{2}{*}{ Df } & \multirow[b]{2}{*}{ Sig. (tailed-2) } & \multirow{2}{*}{$\begin{array}{l}\text { Mean } \\
\text { Difference }\end{array}$} & \multicolumn{2}{|c|}{ Confidence interval of the Difference $95 \%$} \\
\hline & & & & & Lower & Upper \\
\hline VAR00002 & 11.287 & 38 & 000. & 1.13767 & 9336. & 1.3417 \\
\hline
\end{tabular}

The scheduled $\mathrm{T}$ value at the level of significance( $\boldsymbol{\alpha} \leq .0 .05$ ) and degree (63) equals to 2.0 , and in general, it is indicated that the arithmetic mean of all statements is 4.1359 and the calculated $\mathrm{T}$ value equals 11.287 , being greater than the $\mathrm{T}$ value that equal 00 , and a level of significance that equals $(0.000)$ which is less than $(\boldsymbol{\alpha} \leq .0 .05)$, so the null hypothesis $\left(\mathrm{H}_{01}\right)$ is rejected, and, stating that " there is statistically significant impact of the extent of efficiency of applying control environment based on COSO framework to carry out tasks and services transparently, ensure integrity and boost quality and efficiency at Greater Amman Municipality at the level of significance $(\boldsymbol{\alpha} \leq .0 .05)$

$\mathrm{H}_{02}$ : There is no statistically significant impact for the extent of the efficiency of applying risks assessment based on COSO framework to carry out tasks and services transparently, ensure transparency and boost quality and integrity at Greater Amman Municipality at the level of significance $(\alpha \leq \mathbf{0 . 0 5})$ To test this hypothesis, the researcher used the one sample T-test. Results as shown in (Table 10) indicate the views of the study sample individuals.

Table 10. One sample T-test

\begin{tabular}{|c|c|c|c|c|c|c|}
\hline \multicolumn{7}{|c|}{ Test Value $=\mathbf{3}$} \\
\hline & \multirow[b]{2}{*}{$\mathbf{T}$} & \multirow[b]{2}{*}{ Df } & \multirow[b]{2}{*}{ Sig. (tailed-2) } & \multirow{2}{*}{$\begin{array}{l}\text { Mean } \\
\text { Difference }\end{array}$} & \multicolumn{2}{|c|}{ Confidence interval of the Difference $95 \%$} \\
\hline & & & & & Lower & Upper \\
\hline M88 & 7.166 & 16 & 000. & 1.08688 & 7653. & 1.4084 \\
\hline
\end{tabular}

The scheduled $\mathrm{T}$ value at the level of significance $(\alpha \leq \mathbf{0 . 0 5})$ and degree (63) equals to 2.0 , and in general, it is indicated that the arithmetic mean of all statements is 4.0869 and the calculated $\mathrm{T}$ value equals 7.166 , being greater 
than the $\mathrm{T}$ value that equals 2.00 , and a level of significance that equals $(0.000)$ which is less than $(\alpha \leq .0 .05))$, so the null hypothesis (H02) is rejected, and, stating that " there is statistically significant impact of the extent of efficiency of applying risk assessment based on COSO framework to carry out tasks and services transparently, ensure integrity and boost quality and efficiency at Greater Amman Municipality at the level of significance $\alpha \leq . \mathbf{0 . 0 5})$ )".

$\mathrm{H}_{03}$ : There is no statistical significance impact of the efficiency of employing control activities based on COSO framework to carry out tasks and services transparently, ensure integrity, boost efficiency and quality at the Greater Amman Municipality at the level of significance $(\alpha \leq \mathbf{. 0 . 0 5})$. To test this hypothesis, the researcher used the One sample T-test. Results as described in (Table 11) indicate the views of the study sample individuals.

Table 11. One sample T-test

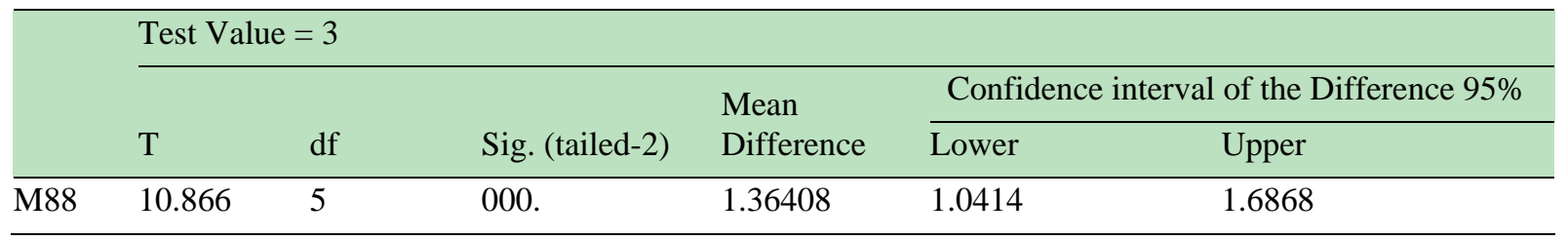

The scheduled $\mathrm{T}$ value at the level of significance $(\alpha \leq \mathbf{0 . 0 5}))$ and degree (63) equals to 2.0 , and in general, it is indicated that the arithmetic mean of all statements is 4.3641 and the calculated $T$ value equals 10.866 , being greater than the T value that equals 2.00 , and a level of significance that equals $(0.000)$ which is less than $(\alpha \leq . \mathbf{0 . 0 5}))$, so the null hypothesis $\left(\mathrm{H}_{03}\right)$ is rejected, and, stating that " there is statistically significant impact of the extent of efficiency of applying control activities based on COSO framework to carry out tasks and services transparently, ensure integrity and boost quality and efficiency at Greater Amman Municipality at the level of significance $(\alpha \leq . \mathbf{0 . 0 5})) "$.

$\mathrm{H}_{04}$ : There is no statistical significance impact of the efficiency of applying appropriate communication systems based on COSO framework to carry out tasks and services to ensure transparency, boost integrity and quality at the Greater Amman Municipality at the level of significance $(\alpha \leq . \mathbf{0 . 0 5})$ To test this hypothesis, the researcher used the One sample T-test. Results as described in (Table 12) indicate the views of the study sample individuals.

Table 12. One sample T-test

\begin{tabular}{|c|c|c|c|c|c|}
\hline \multicolumn{6}{|c|}{ Test Value $=3$} \\
\hline & \multirow[b]{2}{*}{$\mathrm{T}$} & \multirow[b]{2}{*}{ df } & \multirow[b]{2}{*}{ Sig. (tailed-2) } & \multicolumn{2}{|c|}{ Confidence interval of the Difference $95 \%$} \\
\hline & & & & Mean Difference $\overline{\text { Lower }}$ & Upper \\
\hline$\overline{\mathrm{M} 88}$ & 19.037 & 10 & 000. & 1.49932 & 1.6748 \\
\hline
\end{tabular}

The scheduled $\mathrm{T}$ value at the level of significance $(\alpha \leq \mathbf{0 . 0 5}))$ and degree (63) equals to 2.0 , and in general, it is indicated that the arithmetic mean of all statements is 4.4993 and the calculated $\mathrm{T}$ value equals 19.037 , being greater than the $\mathrm{T}$ value that equals 2.00 , and a level of significance that equals $(0.000)$ which is less than $(\alpha \leq . \mathbf{0 . 0 5}))$, so the null hypothesis $\left(\mathrm{H}_{04}\right)$ is rejected, and stating that " there is statistically significant impact of the extent of efficiency of applying appropriate communication systems based on COSO framework to carry out tasks and services transparently, ensure integrity and boost quality and efficiency at Greater Amman Municipality at the level of significance $(\alpha \leq \mathbf{0 . 0 5})) "$.

$\mathrm{H}_{05}$ : There is no statistical significance impact of the efficiency of applying appropriate follow-up activities based on COSO framework to carry out tasks and services to ensure integrity, boost efficiency and quality at the Greater Amman Municipality at the level of significance $(\alpha \leq \mathbf{0 . 0 5})$ to test this hypothesis, the researcher used the One sample T-test. Results as described in (Table 13) indicate the views of the study sample individuals 
Table 13. One sample T-test

\begin{tabular}{lllllll}
\hline & \multicolumn{2}{c}{ Test Value $=3$} & & & \\
\cline { 5 - 7 } & & & & & \multicolumn{2}{l}{ Confidence interval of the Difference 95\% } \\
\cline { 5 - 7 } & $\mathrm{T}$ & df & & Sig. (tailed-2) & Mean DifferenceLower & Upper \\
\hline M88 & 7.509 & 13 & 000. & 1.06484 & 7585. & 1.3712 \\
\hline
\end{tabular}

The scheduled $\mathrm{T}$ value at the level of significance $(\alpha \leq . \mathbf{0 . 0 5}))$ and degree (63) equals to 2.0 , and in general, it is indicated that the arithmetic mean of all statements is 4.0648 and the calculated $\mathrm{T}$ value equals 7.509 , being greater than the $\mathrm{T}$ value that equals 2.00 , and a level of significance that equals $(0.000)$ which is less than $(\alpha \leq \mathbf{. 0 . 0 5})$ so the null hypothesis $\left(\mathrm{H}_{05}\right)$ is rejected, and, stating that " there is statistically significant impact of the extent of efficiency of applying appropriate follow-up activities based on COSO framework to carry out tasks and services transparently, ensure integrity and boost quality and efficiency at Greater Amman Municipality at the level of significance $(\alpha \leq .0 .05) "$.

\section{Results of the Study}

- The independent study variables represented in the extent of the efficiency of applying the internal control components based on COSO framework at Greater Amman Municipality have a positive impact from the point of view of the study sample individuals.

- The communication systems elements ranked first with an arithmetic mean of (4.4993) regarding its effect of applying the internal control components based on COSO framework to carry out tasks and services transparently, ensure integrity and boost quality and efficiency at Greater Amman Municipality, followed by follow-up and control procedures and activities with an arithmetic mean of (4.3641), whereas control environment ranked third with an arithmetic mean of (4.1359), and fourth came response procedures and risks assessment with an arithmetic mean of (4. 0869), finally, the appropriate follow-up element came fifth with an arithmetic mean of (4.0648).

- Study results showed the importance of the integration of the five internal control components based on COSO framework and the need to apply them combined due to the positive effect in applying tasks and services transparently, ensure integrity and boost quality and efficiency at Greater Amman Municipality. This result conforms with the results of (Al-Qada', 2017, Ayagre,et al., 2014) ) and (Joseph, et,al, 2015).

- Study results showed that Greater Amman Municipality has an appropriate environment for the efficiency of the application of internal control components based on COSO framework to carry out tasks and services, ensure integrity and boost quality and efficiency at the Greater Amman Municipality to a high degree. Results show that the highest degree of application was in favor of communication systems component, followed by follow-up and control procedures and activities component, then came the control environment component third, followed by response procedures and risks assessment component, then the appropriate follow-up component in the fifth place.

\section{Recommendations}

- $\quad$ Applying the internal control components based on COSO framework to carry out tasks and services, ensure integrity and boost quality and efficiency at Greater Amman Municipality and develop application methods.

- $\quad$ The need for setting a solid structure of internal control, by adopting the components of the COSO framework when designing the structure of the internal control system and work on its improvement and development to increase the efficiency and efficiency of applying the components of the internal control elements to carry out tasks and services transparently, ensure integrity and boost quality and efficiency at the Greater Amman Municipality.

- $\quad$ The need to ensure continuous monitoring and evaluation of the internal control system, thus helping to identify weaknesses in the system and providing strong evidence of the reliability of the system applied in the Greater Amman Municipality.

- $\quad$ The need to strengthen and improve the control and monitor activities in the Greater Amman Municipality, to rise to the level required to carry out tasks and services transparently, ensure integrity and boost quality and efficiency through separating contradicting functions, and taking appropriate action.

- $\quad$ The need to identify the major risks for each major goal related to the completion of tasks and services to ensure tasks and services are carried out, integrity ensured and quality and efficiency boosted, as well as setting clear policies in relation to reporting the necessary information to staff and develop their performance through performance 
assessment enabling them to perform their duties. Providing appropriate and effective means of communication with internal and external parties as well as setting policies to recruitment since this boosts the good reputation of the Greater Amman Municipality.

- $\quad$ The necessity of conducting more studies with the effect of applying COSO components on the quality of financial reports and on improving internal control in the public sector.

\section{References}

Al Sawalqa, F., \& Atala, Q. (2012). Internal Control and Audit Program efficiency: Empirical Evidence from Jordan. International Business Research, 5(9). https://doi.org/10.5539/ibr.v5n9p128

Al-Qudah, L. (2017). The Impact of Internal Control in accordance with COSO Commission's Decisions on the Analysis of Credit Risk according to the 5C'S Approach in the Jordanian Commercial Banks, Jordan. Journal of Business Administration, 13(4), 497-529.

Angeline, Y., Kiew, H., \& Teng, Y. S. (2018). COSOEnterprise Risk Management: Small -Medium Enterprises Evidence. Asia-Pacific Management Accounting Journal, 13(2), 83-111.

Ayagre, P., Appiah-Gyamerah, I., \&Nartey, J. (2014). The efficiency of Internal Control Systems of banks .The case of Ghanaian banks. International Journal of Accounting and Financial Reporting, 4(2), 377. https://doi.org/10.5296/ijafr.v4i2.6432

Bierstaker, L. (2004). The Impact of Internal Control on Quality Performance: An Empirical Study. Decision Management, 10(5), 3-13.

Ghneimat, A., \& Seyam, W. (2010). Factors affecting the efficiency of the Internal Control Systems in the Jordanian Ministries Jordan. Journal of Business Administration, 4(7), 625-646.

Joseph, O., Albert, O., \& Byaruhanga, J. (2015). Effect of Internal Control on Fraud Detection and Prevention in District Treasuries of Kakamega County. International Journal of Business and Management Invention, 4(1), 47-57.

Mahmud, B., \& Abdallah, S. (2017). Internal Control of Government Unites Under E - Government Developed. The Journal of Administration \& Economics, 111(40), 195-211.

Rubino, M., \& Vitolla, F. (2014). Internal control and financial reporting: opportunities using the COBIT Framework. Managerial Auditing Journal, 29(8), 36-771. https://doi.org/10.1108/MAJ-03-2014-1016

Silmi, A., Adous, S., \& Abu hamour, A. (2014). The Extent of Contribution of COSO Report in Improving the Internal Control at the Industrial Companies at Amman Stock Exchange. Research Journal of Finance and Accounting, $5(14)$.

\section{Websites}

http://www.oecd.org/gov/ethics/corruption-risks-internal-control-mena-AR.pdf

http://www.pscintosai.org/data/files/9A/87/E1/E2/1E927510C0EA0E65CA5818A8/INTOSAI-GOV-9100_e.pdf

https://ec.europa.eu/europeaid/sites/devco/files/strategic-evaluation-cooperation-ec-jordan-1340-main-report-201502 _en.pdf

https://jordankmportal.com/system/resources/attachments/000/000/487/original/Jordan_Fiscal_Environment_Assess ment_2014.pdf?1456660604

https://pefa.org/sites/default/files/assements/comments/JO-Sep11-PFMPR-Public.pd

https://www.ammancity.gov.jo/ar/resource/snews.aspx?id=5097DD10-C5E3-430B-8F3E-4D1CBA6F0EFD 